\title{
Understanding Human Technogenesis: Human Development in the Post-Genomic World
}

\author{
Book review: \\ Challenging nature: the clash between science and spirituality at the new \\ frontiers of life, by Lee Silver. New York: Harper Perennial, 2007; \\ The global genome: biotechnology, politics and culture, by Eugene Thacker. \\ Cambridge, MA: MIT Press, 2006; \\ Biocapital: the constitution of post-genomic life, by R.K. Sunder. Durham, NC: \\ Duke University Press, 2006.
}

\section{DINESH SHARMA ${ }^{1}$}

Different schools of thought within continental philosophy claim that humans are instricably bound up with technology. As Ansell-Pearson states when discussing Bergson, Nietzsche and the transhuman condition, "technology is constitutive prosthetic of the human animal", ${ }^{2}$ or the ontogenesis of the human is dependent on the technics and artificial instrumentation that survive well beyond the individual and are part and parcel of human culture. The emergence of the human represents an extended process of bio-technogenesis or a 'creative evolution' of biological and technological forces, where natural selection has been guided by the natural history of technics and technical interventions. Thus, Bergson has argued that Homo sapiens can be seen as Homo faber because it is a by-product of tools and technology ${ }^{3}$. Similarly, Nietzshe claimed that the human is a transitional figure, "something to be overcome" technology simply an extended phenotype, the result of our hardwired genetic impulse to constantly remake our world? Or is technology interwoven in nature's design through what the anthropologists call 'material culture'? While the answers to these questions may not be easy to grasp, recent scientific discoveries have put humans within striking distance of being able to re-engineer human biological destiny.

At the dawn of the new millennium, while most of the world was abuzz with the Y2K bug potentially tripping the software codes of the emerging global information network, a group of biological and computer scientists powered by the latest supercomputers were decoding the hardware of human life. ${ }^{5}$ In a history-making event, when President Clinton on June 26, 2000 announced the completion of the first survey of the book of life, he pointed to the vast scientific landscape that has been opened by these discoveries: ${ }^{6}$

Today, we are learning the language in which God created life. We are gaining ever more awe for the complexity, the beauty, the wonder of God's most divine and sacred gift. With this profound new knowledge, humankind is on the verge of gaining immense, new power to heal. Genome science will have a real impact on all our lives - and even more, on the lives of our children. It will revolutionize the diagnosis, prevention and treatment of most, if not all, human diseases. In coming years, doctors increasingly will be able to cure diseases like Alzheimer's, Parkinson's, diabetes and cancer by attacking their genetic roots. Just to offer one example, 
patients with some forms of leukemia and breast cancer already are being treated in clinical trials with sophisticated new drugs that precisely target the faulty genes and cancer cells, with little or no risk to healthy cells. In fact, it is now conceivable that our children's children will know the term cancer only as a constellation of stars.

As new genetic pathways are discovered for different human diseases, such as breast cancer, prostate cancer, coronary artery disease, myocardial infarction, obesity and diabetes, the coupling of bioinformatics and genomics is elevating biotechnology to newer heights. ${ }^{7}$ Not unlike physics and chemistry that drove the economic development of the industrialized West, today biology as a 'big science' seems poised to transform the information economy. ${ }^{8}$ According to an Ernst \& Young report, as the biotechnology sector accumulates 30 years of experience (dating back to the Genentech IPO in $1976^{9}$ ), it is generating over US\$60 billion in revenue, booming across the globe (including developing economies in Asia-Pacific), and creating hundreds of human therapies and diagnostic products. ${ }^{10}$ This essay reviews three recent books that provide a closer look at the coming of the biotech century ${ }^{11}$ or what has been called the biotech age. ${ }^{12}$

Several important themes emerge from this collection of books: First, as the biotechnology and bioinformatics industries mature, with the potential to fundamentally reshape modern medicine, the clash between science and spirituality is simply unavoidable. Second, the new biotechnology products fueled by genomics will completely reshape our understanding of human development with their power to mine the human genome. Finally, the rise of biotechnology as a 'big science' is underwritten by speculative market capital, termed "biocapital", partly funded by big pharma and venture capital firms. Biocapital is extending its reach in the form of global human trials to low-income economies, raising the spectre of neocolonialism. Here, I briefly discuss the implications of the biotech revolution for the behavioural and social sciences by focusing on the human-technology nexus, which is transforming human nature as described by the process of human technogenesis or through the co-evolution of humans and technology. ${ }^{13}$ These developments also raise unique challenges for posthuman law as an instrument of social and economic policy. ${ }^{14}$

\section{Stealing Genes from the Gods}

Lee Silver presents a sweeping view of the social policy implications of biotechnology within the highly charged context of science and spirituality. In the ambitious book, Challenging Nature, ${ }^{15}$ he drives home the point that humans do not have a privileged position within "the great chain of being" or scala naturce, and that the human biological evolution as described by many Darwinians has essentially come to a gradual halt as we no longer live in small isolates and are not confronted with daily pressures of survival. ${ }^{16}$ On the other hand, humans are in the position to play dice with the Gods by designing possible human futures through human technological innovation. ${ }^{17} \mathrm{He}$ cautions that a well-reasoned decision supporting biotechnology can only advance humanity, health, and the environment, setting aside any leftist 'new-age' ideas or right-wing conservative ideologies. Depending on your viewpoint, readers may view Silver as possessing Promethean creativity, trying to 
'steal genes' from the Gods, or striking a Faustian bargain in advancing human knowledge.

Silver presents a broad survey of the field of biotechnology and how it is pushing up against some of the highly cherished views about human development. His dispassionate view of a scientist, who sequences genes on a daily basis, covers a broad span of human history tracking the vicissitudes of the gene from ancient biotechnology (including food preservation and animal breeding) to the Human Genome Project. We have always taken up the challenge to tinker with human nature as agriculturalists and industrialists, using new techniques to harness the power of nature. Genomics is the latest scientific leap we have made, except it touches on the very core of what it means to be human. In the final analysis, according to Silver, we must fully embrace the challenge of genomics and lead humanity to the next level of human development, devoid of disease or illness, poverty or famines, and a sustainable biosphere.

Silver has traveled the globe interviewing lay people about the 'ways of knowing' of many spiritual traditions. While acknowledging the persistent utility of spirituality in the minds of everyday folks, he predicts that for the foreseeable future both science and spirituality will continue to be intertwined as counterpoints of human destiny. $\mathrm{He}$ offers an insightful understanding of the resistance to biotechnology as stemming from a central belief that tinkering with human nature calls into question histoire $d$ 'origine or the origin stories of many traditional belief systems. Charles Darwin, as a Christian, was well aware of this and had delayed the publication of The Origin of Species ${ }^{18}$ by almost 20 years. Almost 150 years later, the difference between the Darwinian views of biological evolution as gradual, halting and non-purposive versus religious belief that life is characteristically miraculous and sudden, continues to trouble our conscience collective or the human mind.

Christian fundamentalists (whether Protestant or Catholic) generally believe that human beings receive a soul from God at conception. They shun embryonic stem cell research as a form of killing of human life, but are sympathethic towards agricultural biotechnology. Likewise, there is a growing number of post-Christian Europeans and Americans who have adopted a kind of nature-religion. They espouse a fuzzy belief in God that is empowered by Mother Nature as 'Goddess', a kind of Gaia principle animating the biosphere. Genetically engineered plant genes are seen as an attack on the sovereignty of the Goddess. While on the surface, fundamentalists and postChristian organic food devotees may not have much in common, however, both are deeply rooted in the monotheistic belief against 'playing God', prevalent in the Western developed societies.

In many Eastern cultures, 'playing God' does not carry this negative connotation, where spirit or atman is eternal and self-evolving. These cultures have a view of spirituality that is continuous with human evolution, thus the idea of tinkering with God's natural design may not be anathema. ${ }^{19}$ While there have been recent political stalemates within the stem cell debate in the US, according to Silver, Asian scientists are less likely to be held back by the regulatory pressures that may impede science and policy. ${ }^{20}$ 
Looking at the variation in spiritual forms and practices in different societies, Silver claims that spirituality itself is adaptive and may have a strong genetic underpinning, as documented by the DRD4 gene. He cites evidence that locates the emergence of DRD4 mutation to 30,000 to 50,000 years ago, which then rapidly spread through human populations, coinciding with the archeological evidence of the emergence of the belief in an afterlife and salvation. Silver concludes that the biological evidence coupled with cultural analyses, suggests that the existence of spirituality is biologically determined and does not necessitate divine intervention or intelligent design for its persistence throughout the ages. One of the latest challenges for genomics is to determine the genetic basis for the emergence of the human mind, including the ability to use tools, symbols and language. ${ }^{21}$

Silver does confront the contentious issue of 'embryonic souls', or when germinal life acquires a soul. Before the advent of the microscope the beginning of cellular life was a mystery. From Aristotle to Aquinas the idea of a soul has a long history in Western culture. Where should we draw the line between the life and death of an embryonic soul? The recent case of Rosa Acuna in the Appellate Court of New Jersey and other cases like it around the country underscore the highly politicized environment. Rosa Acuna is a Catholic woman, who received an abortion at 5 weeks of pregnancy and then claimed that her physician, Dr. Sheldon Turkish, did not inform her that life begins at conception. In response to a question from the patient, "My baby was already there?" the physician said something like, "Don't be stupid, it is just some blood". ${ }^{22}$ According to Silver, who consulted on the case on behalf of Dr. Turkish, the idea of embryonic souls is a matter of religious belief, where words like 'dignity', 'sanctity' and 'life' are often equated with the 'natural law', while tampering with the biological processes of human reproduction is considered simply unnatural. The theory of intelligent design is the latest instance of a pro-life view guised as academic science that holds up a Christian doctrine.

Similarly, the recent politicization of stem cell research reflects how those who believe in the 'culture of life' have locked horns again with those who believe in a progressive scientific view. Until 1998 most scientists had no reason to use human embryos in their laboratories. Federal government provided no money for it and most of it was handled by IVF clinics and private funding. The cloning of Dolly, using a technique to create copies of the original DNA later implanted into another sheep's nucleus, brought to the forefront the whole issue of stem cell research. Genes are essentially digital files encoded within the DNA molecules that can be copied and recopied. Regenerative embryonic stem cells can help alleviate many of the hard-totreat ailments through the process of neurogenesis. ${ }^{23}$ Spurred by this new discovery, within five years of the cloning of Dolly, today many scientists believe that research on embryonic stem cells offers the greatest promise for the treatment of many diseases. We are at a critical moment in the development of this technology that can be advanced in a better political climate, unlocking treatments for many of the genetic ailments, especially, neurological or developmental disorders.

Finally, in traveling the globe, Silver takes the reader on a journey through the Amazon rainforest. He is in search of the natural wonder and harmony of Mother 
Nature or 'the paradise lost'. Instead, what he observes is a jungle full of teeming organisms, animals and plants, competing with each other for limited resources in order to survive; Silver states that the Amazon is like the capitalist market economy with intense competition among the same species to outperform each other. Eternal harmony may be difficult to locate in the Amazon, where one wrong move can easily turn you into a prey or the hunted. In other words, the harmony that most 'New Age' religions endow with nature is simply a matter of faith and not an observed fact. When left to its own devices, Mother Nature without human intervention and industry would not know how to direct its course. Natural change is random, non-directional and non-purposive. Based on Silver's observations, the readers may feel a sobering or almost depressing view of life is dawning upon them. As a counterpoint, Silver seems determined to highlight the benefits of biotechnology with the appropriate safeguards for humanity. Silver's scientific outlook is respectful of traditional belief systems, while advancing a deeper understanding of genomics, which makes this book essential reading for those who are either for or against biotechnology. For a somewhat different perspective, we must assess how the biotech revolution is changing the culture and politics of science itself.

\section{Genomic Data Become Flesh}

In a timely and insightful book from the 'science, technology and society' perspective, ${ }^{24}$ Eugene Thacker explains how data have become flesh, how the genomic technologies, the sequencing machines, and the bits of DNA code on computer chips are transforming the very fabric of life. The Global Genome $e^{25}$ elaborates in great detail on the emerging dialectic between biology and technology. Genomic information has become synonymous with the hardware and software involved in the computational process of sequencing and decoding of the human genome. Given the confluence of the university networks, industry and government, the recently coded genomic information is increasingly available online as DNA chips and genetic databases for various disease populations; hence, the genome by definition is a global phenomenon.

However, the age-old tension between biology and technology has now been elevated to the level of political economy as the biotech industry is showing signs of becoming a 'big science' not unlike nuclear physics in its heyday. As an industry that claims to be working on natural matter with high-speed computer chips, it has obliterated the distinction between the natural and the artificial, especially as we acknowledge that any uniquely identified genetic code or pathway can be patented as a separate entity if it is artificially reproduced in the laboratory. In essence, the very substance of life itself has become part and parcel of the production, distribution and consumption cycle within emergent forms of global capitalism.

Thacker's work becomes even more interesting and challenging when he examines the old debates within population genetics around 'race'. While the new population genomics movement is not interested in the issue of 'race', which is essentially a political category rather than a biological one, 'race' nonetheless is intertwined in the attempt to build databases on diverse populations around the world. ${ }^{26}$ Thacker raises the spectre of bio-colonialism using Fanon's example of the colonial doctor who practices medicine in the service of the imperial powers ${ }^{27}$. 
Thacker attempts to rewrite the logic of the production economy for the biotech age. He demonstrates how the very terms used to define classical capitalism are now in need of revision as we are moving towards a biomaterial economy, where life itself represents a biomaterial product (e.g., assay kits, DNA sequencers, genetic databases). Similarly, the threats to our security are increasingly from bio-warfare and bioterrorism, as the government reminds us regularly.

Thacker examines the science of regenerative medicine in great detail. This represents the cutting edge of tissue engineering and a multidisciplinary approach to life sciences. Once a medical approach for repairing failed organs, tissue engineering in the biotech age promises to harness the body's regenerative capacity to recreate perpetual life within living organisms. By genetically manipulating the processes of human growth in vivo, scientists have a vision of the human body that will eventually transcend its materiality, its malfunctions and diseases and of course the biological clock. Indeed, the new biology offers nothing less than material salvation and aspires to be truly the biology of liberation or liberation biology, ${ }^{28}$ the new religion of the biotech age. $^{29}$

The key strength of Thacker's book is its emphasis on the bioinformatics revolution: how the coupling of genomics and informatics will transform life science and its cultural and artistic representations. The author is trained in comparative literature and communication sciences, disciplines steeped in Post-Modern theory, cultural studies and literary criticism; he draws on these sources of knowledge to provide vivid examples of the new media constructions of bio-materiality, bio-media and bio-art. While the book is focused on the globalization of the genome, it does not reach out to low-income economies to understand the impact of biotechnology on diverse populations; for this we must turn to an anthropological account of the commercialization of biotechnology.

\section{Commercialising the Code of Life}

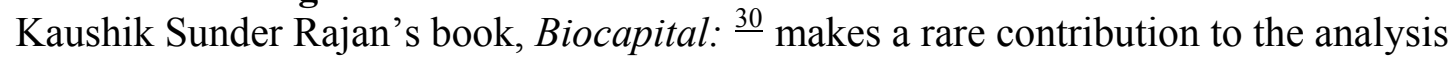
of globalization and commercialization of biotechnology in developed and developing economies. Backed by big-pharma and the buoyant optimism of the market, biotechnology is spreading to far flung places around the world, searching for better business processes, human subjects, clinical expertise, and of course new markets. This raises some fundamental concerns about informed consent and international protocols on clinical research, based on previous case law $^{31}$ and supported by the author's study of Neo-Marxist and Foucauldian theories.

The main strength of the book, the culmination of a doctoral thesis completed at MIT, is the multi-site ethnography that took five years to complete (1999-2004). What the author calls the "upstream and downstream of drug development" is very much influenced by emerging biotechnological products. While big pharma and biotech have very different histories and business models, they meet somewhere near the halfway point of the drug development process. Biotech companies work upstream, trying to move molecules to production past phase 1 and 2 clinical trials to the point where they become potentially interesting targets for a big pharma. Big pharma, with 
its proven track record of taking drugs to profitability, acts as the gatekeeper and lender of capital to foster molecules to maturity. Sunder provides detailed examples of this intricate dynamic as it is played out in the drug development marketplace.

The emergence of generic manufacturers (eg, Teva, Dr. Reddy, Ranbaxy and others) in the developing parts of the world is yet another element that makes the flow of biocapital truly global. Developing economies have different patent rights, which allow manufactures to reverse engineer branded products as generic drugs, driving prices downwards and fostering greater competition with branded drugs. This has fueled a highly competitive legal environment for the branded manufacturers, a majority of which are based in the developed economies of the US, EU and Japan.

As a window on the emerging forms of global bio-capitalism, the author gives a glimpse of the shifting perspectives within the US and Indian biotech industries. Sunder claims that while the US drug industry has shifted towards a 'gifting economy' with inducements for setting up freely accessible databases, economies in the developing world, especially India, are geared towards globalization, aspiring to be business processing shops for the US drug industry. In a kind of economic nationalism, the Indian government promotes the genetic richness of the Indian population as an asset for the American and European drug industry.

The flow and speed of genomic information is truly mind-numbing, a mark of a shift in production, distribution and consumption. Both big pharma and biotech rely on the flow and speed of the information exchange to be ultimately successful in promoting their products. In the increasingly transnational flow of information, bioethics may get short shrift, especially when local views on the exchange of sample and biological materials are not extracted. Sunder makes the important claim that the industry lacks a truly transnational view on the bioethical dilemmas that confront genomics.

Sunder provides many other interesting observations that are corroborated by a recent report on the state of the biotech sector in India. ${ }^{32}$ Conducted by the Center for Global Health at the University of Toronto, the report claims that while India is providing back-office services to many of the major biotech companies and manufacturing several novel biopharma drugs and vaccines, it has not become a major hub for biotech innovation. India has arrived and is poised to make a global contribution, yet faces many local health challenges. Indian biotech is concentrated on at least four types of products and services: low-priced vaccines, non-vaccine drugs and therapies, new product development, and outsourcing or contract services. Harmonisation of the regulatory system, biotech training of personnel, and a focus on the public health of the Indian population would further the Indian biotech industry. Given the limited healthcare spending by the government, these initiatives may be advanced by the inflow of multinational capital or biocapital. In an emerging global economy, this would benefit the Indian population while advancing biotech industry and policy in developed economies.

\section{Technogenesis Redesigns Phylogenesis}

Reviewing these books makes it clear that there is a paradigm-shift underway within the human-technology nexus. The interaction between humans and technology has 
reached an unprecedented dimension, where bioinformatics, robotics and life extension technologies with ever deeper reach into everyday human experience will structurally modify what it means to be human. In an earlier publication, I have outlined the evolutionary dialectic of humans and technology within the context of behavioural sciences - termed "human technogenesis" - which gives rise to new interactive technologies and to new forms and structures of the human mind. ${ }^{33}$

In the post-genomic world, where technology may reshape the very fabric of human life, human-led technogenesis is poised to reproduce in vitro and in vivo phylogenetic evolution. Indeed, the biological sciences may give new meaning to Ernst Haeckel's debunked recapitulation theory, ${ }^{34}$ the idea that ontogeny recapitulates phylogeny can now be represented as technogenesis redesigns phylogenesis. The decoding of the human genome allows the history of our species or phylogenetic evolution to be redesigned with the help of the post-genomic technologies. ${ }^{35}$ In other words, humanled technogenesis is at the precipice of reengineering human life in the laboratory with advanced reproductive technologies, such as IVF, cloning and stem cells. While archaeology and anthropology have been witness to the interaction between humans and technology dating back to pre-historic times, we are approaching a tipping point in this evolutionary dialectic where the decoding of 'the book of life' empowers humans to redesign human development. This shift may not be neat and may be highly contested by many secularists and spiritualists alike. However, technofuturists are claiming that "the singularity is near," where humans empowered with the new technology will transcend biology. ${ }^{36}$

The levels of interaction between technology and human development capture the processes whereby human-led technogenesis redesigns phylogenesis. First, we are intensifying our reliance on newer forms of information and communication technologies such as PC's, cell phones, PDAs and wireless beepers to regulate our behaviour. These interactive tools are reshaping our everyday cultural environment in a significant manner. Second, we are using wearable virtual devices around the ear, eyes, waist, wrist and neck that form a seamless relationship with human body and its daily functions and bio-rhythms. Wearable devices may include monitoring devices we use in a hospital or under clinical observation as well as performance enhancers used in normal functioning, such as wrist-watches, hand-free wireless devices and other types of jewelry.

Next, technology enters the human body and is responsible for regulating deep-rooted biological mechanisms that are inherited and phylogenetic in origin. Medical devices such as pacemakers that are used in chronic conditions to monitor and regulate the human behaviour have been in widespread use. Recently approved and experimental treatments for movement disorders, Parkinson's disease, depression and other neurological disorders rely on neuroimplants. For example, the procedure called Deep Brain Stimulation includes monitoring brain activity via computer devices both inserted and external to the human body, where neuroimplants stimulate parts of the brain to correct for synaptic transmissions ${ }^{37}$ Neurotechnology may go even a step further in treating neurodevelopmental disorders, such as Parkinson's disease, ${ }^{38}$ where the creation of new germinal cells and the pruning of degenerative cells is facilitated by the process called neurogenesis. Using these recent advances in stem cell research, 
technology may completely modulate biology, while the impact of cultural environment may seem remote.

Neuroscientists have also suggested that humans may be implanted with neurochips to achieve higher cognitive potential; neurotechnology companies in collaboration with pharmaceutical companies plan to achieve this goal. ${ }^{39}$ Humanists amongst us may be repulsed by these ideas, yet every society may develop its own adaptive cultural pathway to either adopt or reject these technological developments, just as societies have previously done with the onslaught of industrialization and the information economy.

\section{Liberation Biology Meets Our Posthuman Future}

Studying bioethics at a Jesuit university gave me a sense of moral urgency about medical ethics that touch on human nature, life and death, and God and man. The ethical debates were not mere abstractions; they were about something very serious and impending. Ultimately, they were about our deep humanity and our presumption or the ability to step into God's shoes. Perhaps my upbringing as a Hindu made me sensitive to these debates. Working in the pharmaceutical and biotech sector has returned me to these questions, except now the urgency is even greater as science has advanced much farther. The evidence seems highly suggestive that as technology appropriates and transforms the natural process of human development, it begins to define a posthuman world. ${ }^{40}$ The birth of the posthuman is biologically driven by the contemporary conditions of human existence, which do not foster natural human evolution or natural selection of traits. In other words, non-biological change or the coevolution of humans and technology, of which the biotechnology sector is an ideal example, are driven by different forms of human technogenesis at the institutional level. It is the co-evolution of humans and technology that may lead to the emergence and selection of human traits in the long run. This review has presented a multidisciplinary view of human technogenesis as seen through the genomics revolution, including perspectives from molecular biology, new media, anthropology and social policy.

Indeed, Francis Fukuyama in Our Posthuman Future ${ }^{41}$ claims that the double vision of Orwell and Huxley are fully dawning upon us; the surveillance society created by the information technology revolution has given new meaning to 'Big Brother', while the new forms of reproductive technologies are steadily ushering in the 'Brave New World'. In light of these developments some legal scholars have called for a posthuman law which applies to information and communication technologies, including technologies at the interface of bioinformatics.

Within the legal framework, Sandra Braman has articulated the condition of posthumanism as it pertains to information technologies:

It has been an unspoken assumption that the law is made by humans for humans. That assumption no longer holds: The subject of information policy is [sic] increasingly flows between machines, machinic rather than social values play ever-more important roles in decision-making, and information policy for human society is being supplemented, supplanted, and superceded by machinic decision- 


\section{making. As the barrier between the human and machinic falls with implantation of chips within the body and other types of intimate relationships, and as dependence upon the information infrastructure continues to grow, the question of the rights of technological systems themselves is entering the legal system [...] All of these are manifestations of a transformation in the legal system so fundamental that it may be said that we are entering a period of posthuman law. ${ }^{42}$}

As the genomic gold rush picks up pace, the tensions between human law and posthuman culture is likely to escalate. Judging by a recent review, the race to uncover the genetic basis of each human disease with large cohorts of cases and controls is underway. ${ }^{43}$ There is a rush to patent the information and commercialize even the smallest of genomic nuggets. While approximately $20 \%$ of the human genome has been patented, this number is likely to increase rapidly. This makes the ultimate step of linking genes with a disease and in turn with a particular therapy that much more difficult. For instance, the development of a panel of gene markers for a disease might take negotiations with multiple and diverse interests who may own different components of the patent for that disease. As it has been aptly stated, "Who then owns the genome?"44 How can we allow for an open exchange of information that advances science and policy for the common good? These are some of the challenges confronting us as liberation biology, the new religion, reconstitutes life in the posthuman world.

\section{Patenting Life 2.0}

The science fiction writer Michael Crichton has argued that an underfinanced and understaffed US patent office (USPTO) misinterpreted the Supreme Court precedence when it allowed genes to be patented. ${ }^{45}$ "Genes aren't human inventions; they are features of the natural world," he wrote in a New York Times article. Jeremy Rifkin and many other activists would claim that patenting genes has blocked innovation and patient care. ${ }^{46}$ Genomic discoveries are a global public health good, part and parcel of our common heritage. ${ }^{47}$ On the other hand, a new generation of scientists called Synthetic Biologists, are creating synthetic organisms, challenging nature's monopoly on the plethora of living organisms. They want to patent everything under the sun and rewrite the code of life dubbed 'Life 2.0' ${ }^{48}$ The task of the USPTO has become increasingly complex in the post-genomic world.

Life science and biotechnology is an expensive enterprise and relies on strong patent protection for innovation. However, a string of recent decisions have made it tougher for life science patents to be acquired and defended. In the eBay, Inc. v.

MercExchange, L.L.C. (May, 2006), the US Supreme Court reduced permanent injunctions for infringements of a patent, weakening the value of patent rights. ${ }^{49}$ In MedImmune, Inc. v. Genentech, Inc. (Jan, 2007), the court made it easier for a patent to be challenged by a licensee. ${ }^{50}$ Most recently in KSR International, Inc. v. Teleflex, Inc., the US courts lowered the obviousness standard for a patent, making it easier to invalidate a patent. ${ }^{51}$

These recent decisions also reflect the overall tone of the Patent Reform Act of 2007, which has been heavily driven by the software development industry. ${ }^{52}$ Obvious 
limitations for biotechnology patents consist of longer incubation periods and longer claims of exclusivity. Unlike the software products, biotech products exist in a highly regulated environment, with much greater risks of liability. Thus, it is currently believed by many legal experts that the forthcoming changes from the USPTO can be damaging for the life sciences, especially, when the limitations to the continuation claims are considered which makes it difficult to obtain full coverage of a biotechnology invention. ${ }^{53}$

The technical discussions about patents have real-life implications for human development. Human development as defined by many developmental agencies reflects the progressive aim of improving the lives and health conditions of people around the world. While the laws dealing with the post-genomics revolution are in flux in the US, there is little attention paid to these issues in developing countries. However, in a globalized world where outsourcing of biotechnology products is fast becoming the norm, ignoring the emerging economies in the developing world is a luxury we can not afford. The burden of disease from life-long, genetic disorders can be gradually lifted if the legal environment is conducive to innovation in diagnostics, drug development and delivery of healthcare. As the biotechnology discoveries begin to accumulate, we are facing an uphill climb, with many regulatory, financial, and business challenges towards creating open access to genomics "public health goods", 54 for populations around the world.

\footnotetext{
${ }^{1}$ Institute for International and Cross-Cultural Psychology, St. Francis College, Brooklyn Heights, NY dinesh.sharma@post.harvard.edu or dinesh.sharma@att.net

${ }^{2}$ K. Ansell-Pearson. 1997. Viroid Life: Perspectives on Nietzsche and the Transhuman Condition. Routledge: New York; also see K. Ansell-Pearson. 1999. The Germinal Life: The difference and repetition of Deleuze. New York, Routledge.

${ }^{3}$ Bergson, H. (1913). Creative evolution. New York: Henry Holt.

${ }^{4}$ Neitzche, F. (2003). Thus spake Zarathustra (translation by Thomas Wayne). New York: Algora Publishing.

${ }^{5}$ The history of the landmark event and the pioneering work of Craig Venter has been widely documented. See Celera Genomics: http://www.celera.com/celera/history

${ }^{6}$ Clinton's comments on the signing of the Executive order 13145 are available at http://www.genome.gov/10001356

${ }^{7}$ E.J. Topol, S.S. Murray \& K.A. Frazer. The Genomics Gold Rush. JAMA 2007; 298(2): 218-221.

${ }^{8}$ F. Dyson. Our Biotech Future. The New York Review of Books 19 July 2007; 54 (12).

${ }^{9}$ The Genentech IPO in 1980 is a landmark as this was the first biotech company based on the genesplicing technique or the recombinant DNA technology, where pieces of the DNA from one species was inserted into the genome of another species. The founders, Paul Berg, Herbert Boyer and Stanley Cohen, filed for patent on their gene-splicing technique in 1974 and assigned all royalties to their respective universities, UCSF and Stanford.

${ }^{10}$ Ernst \& Young. 2007. Beyond Borders: E\&Y Biotech Report.

http://www.ey.com/global/content.nsf/International/Biotechnology_Library_Beyond_Borders_2007

${ }^{11}$ J. Rifkin. 1999. The biotech century: harnessing the gene and remaking the world. New York:

Tarcher/Putnam.

${ }^{12}$ R.W. Oliver. 2000. The coming biotech age: the business of bio-materials. New York: McGraw Hill.

${ }^{13}$ D. Sharma. 2004. Human technogenesis: cultural pathways through the information age. New York: John Wiley.

${ }^{14}$ S. Braman. Posthuman Law. First Monday: peer reviewed Internet journal 2002; 7(12).

http://www.firstmonday.org/issues/issue7 12/braman/; Also see J. L. Amestoy. Uncommon Humanity:
} 
Reflections on Judging in a Post-Human Era. New York University Law Review, 2003; 78(3): 15811595.

${ }^{15}$ L. Silver. 2007. Challenging nature: the clash between science and spirituality at the new frontiers of life. New York : Harper Perennial.

${ }^{16}$ See the Hall of Human Origins at the AMNH website:

http://www.amnh.org/exhibitions/permanent/humanorigins/future/

${ }^{17}$ This view is expressed by growing number of scientists. See G. Stock. 2002. Redesigning humans: our inevitable genetic future. Boston: Houghton Mifflin.

${ }^{18} \mathrm{C}$. Darwin. 1859. The origins of species. London: John Murray.

${ }^{19}$ The parallel between physical and spiritual evolution was expressed by Sri Aurobindo, a modern Indian mystic and philosopher who envisioned that humans are evolving a supra-mental consciousness through the process of spiritual evolution which will in turn transform their material existence on earth; his ideas were similar to the ideas of the French philosopher Teilhard de Chardin. See Aurobindo's Mind of Light (Auroville, 1956).

${ }^{20}$ This observation is supported by a thought provoking editorial. See P. Mishra. How India Reconciles Hindu Values and Biotech. New York Times, 21 August 2005.

${ }^{21}$ Silver claims that the research may close in on a constellation of genes that are responsible for the mutations that led to the emergence of the human mind. Interestingly, FOXP2 is a gene found in people who have all human defining characteristics except they are not able to use language.

${ }^{22}$ See the story entitled "New Jersey Court Rules Jury Must Decide If Abortion Terminates a Life" at http://www.lifesite.net/ldn/2006/apr/06040705.html

${ }^{23}$ F.H. Gage. Neurogenesis in Adult Brain. The Journal of Neuroscience 2002; 22(3): 612-613; G. Kempermann, L. Wiskott \& F. Gage. Functional significance of adult neurogenesis. Current Opinion in Neurobiology 2004; 14: 186-191; G. Kempermann. 2005. Adult neurogenesis: stem cells and the neuronal development in the adult brain. New York: Oxford Press.

${ }^{24}$ This is a theoretical view espoused by the MIT's interdisciplinary program that examines the 'human-built world' from the standpoint of science, humanities and the social sciences.

${ }^{25}$ E. Thacker. 2006. The global genome: biotechnology, politics and culture. Cambridge, MA: MIT Press.

${ }^{26}$ The well-known instance of population genomics is of course the Icelandic project led by DeCode Genetics: http://www.decode.com/

${ }^{27}$ Fanon, F. (1959). A dying colonialism. New York: Grove Press.

${ }^{28}$ R. Bailey. 2005. Liberation biology: the scientific and moral case for the biotech revolution. New York: Prometheus Books.

${ }^{29}$ B. Alexander. 2003. Rapture: how biotechnology became the new religion. New York: Basic Books.

${ }^{30}$ R.K. Sunder. 2006. Biocapital: the constitution of post-genomic life. Durham, NC. Duke Press.

${ }^{31}$ California Supreme Court ruled that the Regeants of California had responsibility to John Moore for full disclosure in order to obtain informed consent for a procedure; 51 CAL. 3D 120 (1990).

${ }^{32} \mathrm{~S}$. Frew, R. Rezaie, S. Sammut, et al. India's health biotech sector at a crossroads. Nature Biotechnology 2007; 25 (4): 403-417.

${ }^{33}$ D. Sharma. 2004. Human technogenesis. New York: John Wiley; The term technogenesis is borrowed from the geological sciences, where it refers to the changes in the earth's sphere and the environment due to the introduction of technological changes; for instance, the construction of a hydraulic dam changes the water flow, river beds, and irrigation of agricultural land; the term technogenesis is also used in science fiction literature (see Syne Mitchel) and of course in technology incubation (see Steven's Institute of Technology). Human technogenesis as used here refers to the process of co-evolution of technology and human nature as driven by the biotech sector.

${ }^{34}$ Recapitulation theory has long been repudiated within biology, even though it still appears in textbooks. Here, the reference is to simply evoke an analogy, not to describe a hard principle. For an update on the recapitulation theory, see S.J. Gould. 1977. Ontogeny and phylogeny. Cambridge Mass.: Belknap Press of Harvard University Press.

${ }^{35}$ L. Silver. Playing God: Life 2.0. Newsweek (International Edition), June 4, 2007.

${ }^{36}$ See R. Kruzweil. 2000. The Singularity is near: when humans transcend biology. New York: Viking. Others, like Gregory Stock in Redesigning humans: our inevitable genetic future (2002), claim that humans will functionally fuse with technology, but will never fully merge with them. In other words, we will never be cyborgs, half humans-half machines, but rather fryborgs, that is functionally using 
technology even if it is within the body without losing our physical boundaries; this is the kind of world we already live in where we rely on tools, devices and gadgets to orient ourselves.

${ }^{37}$ For detailed understanding of Deep Brain Stimulation, see the Cleveland Clinic's neuroscience Web

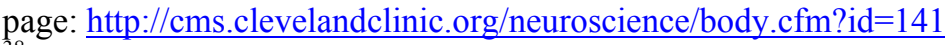

${ }^{38}$ Gage, op. cit. note 21; G. Kempermann, L. Wiskott \& F. Gage. Functional significance of adult neurogenesis. Current Opinion in Neurobiology 2004; 14: 186-191.

${ }^{39}$ K. Thar. 2006. Brain cells fused with computer chips. LiveScience 27 March 2006.

http://www.livescience.com/health/060327 neuro_chips.html; Also see M. Bani-Yaghoud et al.

Neurogenesis and neuronal communication on micropatterned neurochips. Biotechnology and bioengineering 2005; 92:3: 336-345.

${ }^{40}$ The idea of posthumanism has roots in Western thinking which attempts to transcend human limitations by eradicating illness, prolonging aging, and enhancing human potential through technology. See S. Post. 2003. Tranhumanism and posthumanisn. In Encyclopedia of bioethics. S. Post Eds., New York: MacMillan Publishers: 2517-2520. Posthumanism may have diverse roots in Asian philosophy which needs further exploration.

${ }^{41}$ F. Fukuyama. 2002. Our posthuman future: consequences of the biotech revolution. New York: Picador.

${ }^{42}$ S. Braman. Posthuman law. First Monday: Peer Reviewed Internet journal 2002; 7(12) http://www.firstmonday.org/issues/issue7_12/braman/

${ }^{43}$ E.J. Topol, S.S. Murray \& K.A. Frazer. The Genomics Gold Rush. JAMA 2007; 298(2): 218-221.

${ }^{44}$ S.A. Brown, Q.T. Dickinson, S. Fodor, et al. The Genetic Age: Who owns the Genome? John Marshall Review of Intellectual Property Law 2002; 2:006, 5-29.

${ }_{45}$ M. Crichton. Patenting life. New York Times; 13 February 2007.

${ }^{46}$ J. Rifkin. 1999. The biotech century: harnessing the gene and remaking the world. New York: Tarcher/Putnam.

${ }^{47}$ H. Thorsteinsdóttir, A. Daar, R. Smith \& P. Singer. Genomics - a global public good? The Lancet 2003; 361(9361): 891-892.

${ }^{48}$ L. Silver. Life 2.0. Newsweek International. 4 June 2007.

${ }^{49} \mathrm{http}: / / w w w . s u p r e m e c o u r t u s . g o v / o p i n i o n s / 05 p d f / 05-130 . p d f$

$50 \mathrm{http}: / /$ www.supremecourtus.gov/oral arguments/argument transcripts/05-608.pdf

$51 \mathrm{http} / / /$ www.supremecourtus.gov/oral arguments/argument transcripts/04-1350.pdf

52 B. Erickson. Protecting biotech innovations. Industrial Biotechnology 2007; 3(3): 189-189.

${ }^{53}$ California Healthcare Institute. 2007. Impact of patent law changes on biomedical investments and innovation. http://www.chi.org/uploadedFiles/CHI\%20Patent\%20Law\%20changes\%20paper.pdf

${ }^{54}$ Thorsteinsdóttir et al, op. cit. note 44; B.M. Knoppers. Of genomics and public health" building public "goods"? CMAJ 2005; 173(10), 1185-1186. 